\title{
Società Italiani Uniti: do triunfo à decadência. A emergência do fascismo*
}

Rosane Siqueira Teixeira*

\section{RESUMO}

O presente artigo apresenta parte do resultado da pesquisa realizada sobre a Società Italiani Uniti, uma associação italiana marcada pela emergência do fascismo, que existiu em Araraquara (SP) entre os anos de 1920 e 1941. Pretende-se traçar a sua trajetória, do triunfo à decadência, discutindo suas funçóes, coesão e consenso.

Palavras-chave: associação italiana; fascismo; estatutos.

\begin{abstract}
This paper presents part of a research about the Società Italiani Uniti, an Italian association existing in Araraquara (SP) between 1920 and 1941, during the rise of Fascism. The research traces its trajectory, from triumph to decadence, discussing its activities, cohesion and consensus.
\end{abstract}

Keywords: Italian association; Fascism in Brazil; statutes.

Artigo recebido em 17 de janeiro de 2013 e aceito em 28 de fevereiro de 2013.

* Este artigo é parte da introduçáo e do segundo capítulo de minha tese de doutorado, financiada pela Fapesp e pela Capes (doutorado sanduíche em Roma, Itália), intitulada Associaçóes italianas no interior paulista num espaço partilhado. Nacionalismo e italianidade sob a perspectiva da história local, defendida em 2011 junto ao Programa de Pós-Graduação em Sociologia da Universidade Federal de São Carlos (UFSCar). Agradeço aos pareceristas anônimos da Topoi pelos comentários e sugestóes feitos para o aprimoramento deste artigo.

** Doutora em sociologia pela Universidade Federal de São Carlos, pesquisadora na Universidade Federal de São Carlos. São Carlos, SP, Brasil. E-mail: rosane.steixeira@gmail.com. 
Figura 1

Parte interna da Società Italiani Uniti, Araraquara, s.d.

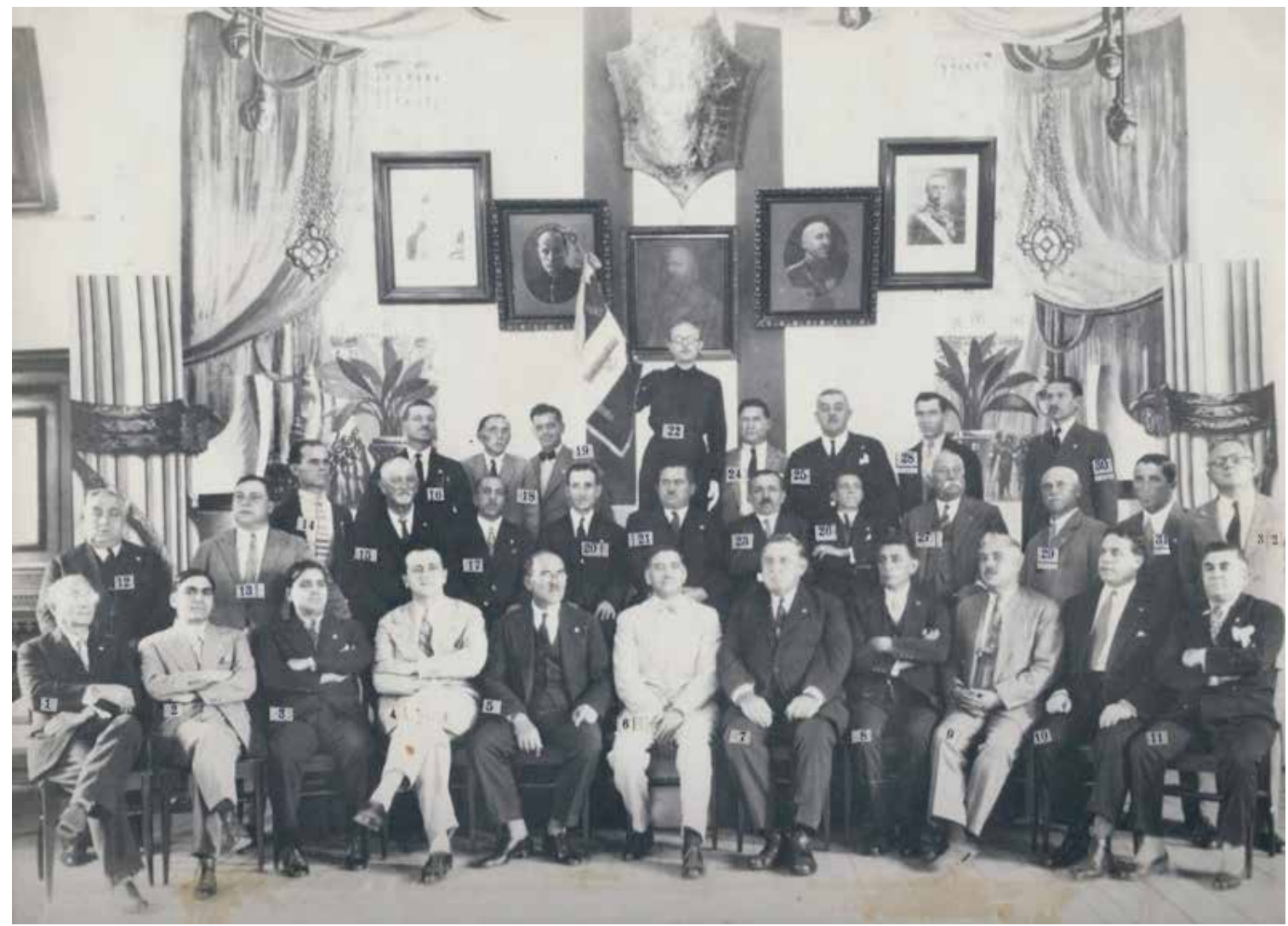

Fonte: Museu da Imagem e do Som, Araraquara.

Leia-se: 1. Antonio Nusdeo; 2. Raphael Barbieri; 3. Domingos Barbieri; 4. Dr. Giuseppe Aufiero Nipote; 5. Gaspar Abritta; 6. Dr. Giuseppe Aufiero; 7. Augusto Bignardi; 8. Nicola Barbato; 9. José Palamone Lepre; 10. Affonso Lombardi; 11. Oswaldo Negrini; 12. Agostino Tucci; 13. Corrosoni; 14. Marziali Billi; 15. Augusto Zenerin; 16. Guido Michetti; 17. Michele Loria; 18. Alberto Cestari; 19. Pedro Martini; 20. Caetano Mirabelli; 21. Enrico Somenzari; 22. Adolpho Criscini; 23. Pietro Galeazzi; 24. Antonio Blundi; 25. Caetano Passeto; 26. Janoario Arena; 27. Vincenzo Gravina; 28. Pietro Firminano; 29. Temistocles Fioretti; 30. Arturo Rizzoli; 31. Giuseppe Storino; 32. Enrico Lupo.

\section{Introdução}

Este artigo revela um contexto da imigração italiana ainda pouco estudado no Brasil. Ele pretende colocar em foco parte do resultado de uma pesquisa realizada com duas associaçóes italianas, uma de beneficência e outra de socorro mútuo, envolvidas pelo fascismo, concentrando-se prioritariamente em uma delas: a Società Italiani Uniti, ${ }^{1}$ que existiu em Araraquara entre os anos de 1920 e 1941. Na verdade, num levantamento quantitativo recentemente organizado por Viscardi ${ }^{2}$ sobre as produções do tema das associações mutuais no Brasil, desenvolvidas entre o período de 1970 e 2010, constatou-se que a partir do ano de 2001 houve um crescimento considerável. De fato, esse

\footnotetext{
${ }^{1}$ Doravante SIU.

${ }^{2}$ VISCARDI, Cláudia M. R. O estudo do mutualismo: algumas considerações historiográficas e metodológicas. Revista Mundos do Trabalho, v. 2, n. 4, p. 23-39, 2010.
} 
tema apresenta uma notável dimensão. Contudo, se compararmos com a produção historiográfica existente nos países latino-americanos ${ }^{3}$ e europeus, ${ }^{4}$ percebe-se que, no Brasil, ele ainda se encontra em fase inicial de pesquisas.

A recente produção acadêmica tem dado uma significativa atenção à análise do mutualismo no mundo do trabalho 5 na medida em que ela questiona se há ou não relaçóes de continuidade entre as mutuais e as associaçôes de resistência operária. Outras produçôes como Trento, ${ }^{6}$ Bertonha, ${ }^{7}$ Martins ${ }^{8}$ e Oliveira ${ }^{9}$ estudaram o tema em trabalhos mais amplos.

Entre os estudos em curso, destacam-se os de Viscardi, ${ }^{10}$ que se concentram nas mutuais localizadas em Minas Gerais, especificamente em Juiz de Fora, com ênfase nas complexas relaçóes entre mutualis-

\footnotetext{
${ }^{3}$ Entre eles: ESTRADA, Baldomero. La colectividad italiana de Santiago de Chile a traves de la sociedad de socorros mutuos "Italia" (1880-1920). In: DEVOTO, Fernando J.; MIGUEL, Eduardo J. (Comp.). Asociacionismo, trabajo e identidad etnica. Los italianos en América Latina en una perspectiva comparada. Buenos Aires: Cemla-CSER-IEHS, 1992. p. 59-75; SILBERSTEIN, Carina Frid de. Las opciones educativas de la comunidad italiana en Rosario: las escuelas mutualistas y el colegio Salesiano (1880-1920). In: DEVOTO, Fernando J.; MIGUEL, Eduardo J. (Comp.). Asociacionismo, trabajo e identidad etnica, op. cit. p. 101-133; BESTENE, Jorge O. Formas de asociacionismo entre los sirio-libaneses en Buenos Aires (1900-1950). In: DEVOTO, Fernando J.; MIGUEL, Eduardo J. (Comp.). Asociacionismo, trabajo e identidad etnica, op. cit. p. 115-133; FERNÁNDES, Alejandro E. El mutualismo español en un barrio de Buenos Aires: San Jose de Flores, (1890-1900). In: DEVOTO, Fernando J.; MIGUEL, Eduardo J. (Comp.). Asociacionismo, trabajo e identidad etnica, op. cit. p. 135-168; DEVOTO, Fernando J. Participación y conflictos en las sociedades italianas de socorros mutuos en Buenos Aires y Santa Fe. In: ___ Estudios sobre la emigración italiana a la Argentina en la segunda mitad del siglo XIX. Collana: Pubblicazioni del Seminario di Studi Latinoamericani dell'Università di Sassari, Serie Studi — I; Napoli: Edizioni Scientifiche Italiane, 1991. p. 143-197; DEVOTO, Fernando J. La experiencia mutualista italiana en la Argentina: un balance. In: DEVOTO, Fernando J.; MIGUEL, Eduardo J. (Comp.). Asociacionismo, trabajo e identidad etnica, op. cit. p. 169-266; BAILY, Samuel. Las sociedades de ayuda mutua y el desarrollo de una comunidade italiana en Buenos Aires, 1858-1918. Desarrollo económico, Buenos Aires, v. 21, n. 21, p. 484-514, ene./mar. 1982.

${ }^{4}$ Entre eles: MARUCCO, Dora. Lavoro e solidarietá popolare: forme, modelli, rapporti del mutuo soccorso italiano. In: DEVOTO, Fernando J.; MIGUEL, Eduardo J. (Comp.). Asociacionismo, trabajo e identidad etnica, op. cit. p. 9-29; TRENTO, Angelo. Le associazioni italiane a São Paulo: 1878-1960. In: DEVOTO, Fernando J.; MIGUEL, Eduardo J. (Comp.). Asociacionismo, trabajo e identidad etnica, op. cit. p. 31-57; ROSOLI, Gianfausto. L'associazionismo cattolico degli emigrati italiani in América tra '800 e '900. In: DEVOTO, Fernando J.; MIGUEL, Eduardo J. (Comp.). Asociacionismo, trabajo e identidad etnica, op. cit., p. 77-99.

${ }^{5}$ BATALHA, Cláudio H. M. Sociedade de trabalhadores no Rio de Janeiro do século XIX: algumas reflexóes em torno da formação da classe operária. Cadernos AEL, Campinas, v. 6, n. 10-11, p. 41-68, 1999; FORTES, Alexandre. Da solidariedade à assistência: estratégias organizativas e mutualidade no movimento operário de Porto Alegre na primeira metade do século XX. Cadernos AEL, Campinas, v. 6, n. 10-11, p. 171-220; BIONDI, Luigi. Entre associaçôes étnicas e de classe: os processos de organização política e sindical dos trabalhadores italianos na cidade de São Paulo (1890-1920). Tese (doutorado em história) - Instituto de Filosofia e Ciências Humanas, Universidade Estadual de Campinas, Campinas, 2002.

${ }^{6}$ TRENTO, Angelo. Do outro lado do Atlântico. São Paulo: Nobel; Istituto Italiano di Cultura di San Paolo; Instituto Cultural Ítalo-Brasileiro, 1989.

${ }^{7}$ BERTONHA, João Fábio. Sob o signo do fascio: o fascismo, os imigrantes italianos e o Brasil, 1922-1943. Tese (doutorado em história) - Instituto de Filosofia e Ciências Humanas, Universidade Estadual de Campinas, Campinas, 1998.

${ }^{8}$ MARTINS, José de Souza. Trabalho e comunidade. In: A imigração e a crise do Brasil agrário. São Paulo: Pioneira, 1973; __. Subúrbio. Vida cotidiana e história no subúrbio da cidade de São Paulo: São Caetano, do fim do império ao fim da República Velha. São Paulo: Hucitec, 1992.

${ }^{9}$ OLIVEIRA, Flávia Arlanch Martins de. Impasses no novo mundo: imigrantes italianos na conquista de um espaço social na cidade de Jaú, (1870-1914). São Paulo: Editora Unesp, 2008.

${ }^{10}$ VISCARDI, Cláudia M. R. Proteção e socorro: um estudo das associaçôes mutualistas e beneficentes no pós-abolição. In: SIMPÓSIO NACIONAL DE HISTÓRIA, XXII, 2003, João Pessoa. Anais do XXII Simpósio Nacional de História. João Pessoa: Associação Nacional de História; Universidade Federal da Paraíba, 2003. v. 1, CD-ROM; __ . Mutualismo e filantropia. In: ENCONTRO REGIONAL DE HISTÓRIA DA ANPUH-MG, XV, 2004, Juiz de Fora. Anais do XV Encontro Regional de História da ANPUH-MG. Juiz de Fora: UFJF, p. 1-12, 2004; __. As experiências mutualistas de Minas Gerais: um ensaio interpretativo. In: ALMEIDA, Carla Maria de; OLIVEIRA, Mônica Ribeiro de (Org). Nomes e números: alternativas metodológicas para a história econômica e social. Juiz de Fora: UFJF Editora, 2006, p. 305-322.
} 
mo e filantropia. Esse tema tem como referência o trabalho pioneiro de De Luca, ${ }^{11}$ que, ao estudar as inúmeras associaçóes de socorros mútuos espalhadas pelas principais cidades do estado de Sáo Paulo, focalizando sobretudo a capital e a cidade de Santos, teve como argumento principal que estas não deram origem e nem se confundem com o sindicalismo. Outro trabalho importante, também considerado pioneiro, é o de Kushnir, ${ }^{12}$ que explora o interior de duas associaçóes de socorros mútuos pertencentes a imigrantes judeus, uma localizada no Rio de Janeiro e outra em São Paulo, e mostra o mundo da prostituição de mulheres judias e suas buscas pela manutenção de uma identidade étnico-religiosa. Por sua vez, merece destaque o estudo de Silva $\mathrm{Jr}^{13}$ Ele examinou a relação das associaçôes mutuais com o Estado, a elite econômica e os potentados locais e verificou que havia troca de favores entre essas instituiçôes. Silva Jr. concluiu que, por um lado, garantiam-se os benefícios e a proteção, por outro, obtinham-se favores políticos. Ele apontou que o mutualismo pode ser usado como estratégia para atingir determinados fins, especialmente o de evitar o descenso social. Um dos trabalhos mais recentes desse tema foi desenvolvido por Furlanetto ${ }^{14}$ em sua tese de doutorado, que teve como foco principal as associaçôes mutuais italianas da cidade de Ribeirão Preto (SP). Ela procurou demonstrar as diferentes estratégias utilizadas pelos italianos no contexto das associaçôes. De maneira geral, nota-se que as discussóes giram em torno da sociabilidade, da solidariedade mútua e do reforço da identidade étnica.

Aliás, estes foram os temas que mais despertaram o interesse no debate sobre as associaçóes italianas fundadas entre o final do século XIX e início do XX, não só no Brasil como no exterior. Nesse sentido, ainda pouco se sabe sobre a emergência do fascismo no interior das associaçóes numa perspectiva local. Logo, o estudo sistemático realizado com a SIU oferece uma interpretação a essa temática.

Este artigo, portanto, tem por finalidade traçar a trajetória da SIU marcada pela emergência do fascismo, do triunfo à decadência, vislumbrando como ela mobilizava suas funçóes para manter a colônia coesa, visando alcançar o consenso. Para tal, toma como guia os seus Estatutos; o histórico da SIU demonstra a necessidade de reformulá-los como forma de se adequar tanto à dinâmica interna do grupo, como para atender às mudanças de conjunturas do Brasil e do regime fascista. Desse modo, não se pode compreender a SIU separadamente de seus Estatutos, pois eles registram a definição e execuçáo dos objetivos sociais.

Ao mesmo tempo, não se podem analisar os anos de 1920 e 1930 sem privilegiar o impacto do fascismo sobre a vida comunitária italiana. ${ }^{15}$ Deve-se ter em conta que, no transcorrer da década de 1920 , o objetivo do regime fascista era o de expandir as fronteiras culturais e econômicas italianas por meio dos próprios italianos residentes em outros países. Já no decorrer dos anos de 1930, o regime fascista procurou expandir a ideologia do fascismo, ${ }^{16}$ de modo que a penetraçáo fascista na coletividade italiana no Brasil processou-se de forma diferenciada nos anos 1920 em relação aos anos $1930 .{ }^{17}$

\footnotetext{
${ }^{11}$ DE LUCA, Tânia Regina. O sonho do futuro assegurado. São Paulo: Contexto, 1990.

${ }^{12}$ KUSHNIR, Beatriz. Baile de máscaras: mulheres judias e prostituição: as polacas e suas associações de ajuda mútua. Rio de Janeiro: Imago, 1996.

${ }^{13}$ SILVA JR., Adhemar L. Condicionantes locais no estudo do socorro mútuo (Rio Grande do Sul: 1854-1889). In: Locus, Revista de História, Juiz de Fora, v. 5, n. 2, p. 73-88, 1999.

${ }^{14}$ FURLANETTO, Patrícia G. O associativismo como estratégia de inserção social: as práticas sócio-culturais do mutualismo imigrante em Ribeirão Preto (1895-1920). Tese (doutorado em história social) — Faculdade de Filosofia, Letras e Ciências Humanas, Universidade de São Paulo, São Paulo, 2007.

15 TRENTO, Angelo. Le associazioni italiane a Sáo Paulo: 1878-1960. In: DEVOTO, Fernando J.; MIGUEL, Eduardo J. (Comp.). Asociacionismo, trabajo e identidad etnica, op. cit. p. 31-57.

${ }^{16}$ BERTONHA, João Fábio. O Brasil, os imigrantes italianos e a política externa fascista, 1922-1943. Revista Brasileira de Politica Internacional, v. 40, n. 2, p. 106-130, 1997; Sob o signo do fascio, op. cit.

${ }^{17}$ TRENTO, Angelo. Do outro lado do Atlântico, op. cit.; BERTONHA, João Fábio. O Brasil, os imigrantes italianos e a política externa fascista, 1922-1943, op. cit.; . Sob o signo do fascio, op. cit.
} 
O artigo encontra-se estruturado da seguinte forma: após a introdução, ele foi dividido em quatro partes principais: a primeira esboça um histórico da SIU, dando ênfase às suas funçóes; e as três partes restantes se referem aos três Estatutos que a SIU possuiu durante sua trajetória: o primeiro em 1921; o segundo em 1931; e, finalmente, o terceiro em 1938. Antes, porém, de iniciar o assunto essencial, convém fazer rapidamente algumas consideraçóes.

Um estudo mais aprofundado dessa associação só foi possível porque tive acesso às atas das assembleias. Sem elas não poderia romper um silêncio de mais de cem anos. Esses corpos documentais são livros raros, pois muitos deles foram destruídos (ou guardados e deteriorados com o passar dos anos) quando o governo de Getúlio Vargas decretou guerra contra os países do eixo, em 1942, dos quais a Itália fazia parte, restringindo a vida associativa dos italianos no Brasil. Todavia, assim como tanto outros, eles são documentos limitados.

As atas são compostas por registros manuscritos em língua italiana, o que ilustra e demarca o elo de identidade do grupo com sua cultura. ${ }^{18}$ Elas são o que denomino de diário de reticências, pois suas páginas contêm todos os fatos ocorridos durante as sessóes, porém, muitas vezes se percebe que certos registros ficam ocultos, sobretudo quando há conflitos, disputas e rupturas entre os membros. Na verdade, os seus registros são uma maneira de conceder autenticidade aos assuntos das reuniôes e de inscrever a história da associação. Se, por um lado, o que dificulta a análise dessas atas é o espaço de tempo que ocorre entre uma reunião a outra, o qual consequentemente deixa uma ausência de informaçóes úteis; por outro, concordo com Martins, ${ }^{19}$ a leitura delas aponta "as mudanças sociais que foram ocorrendo na localidade através das mudanças no modo de ver as coisas". Ademais, por meio delas, é possível observar os valores baseados em sentimentos de nacionalidade e de defesa da italianidade, as conquistas, as inquietações que permeavam os grupos e o apogeu e declínio dessa associação. Elas são, sem sombra de dúvida, preciosos documentos.

O trabalho que deu origem a este artigo foi desenvolvido à luz da metodologia da "história local". Nela, a relação tempo-história é de fundamental importância. Enquanto a história dos grandes processos trabalha com a noção de um tempo uniforme, comum a todos os espaços, para a história local importa o "tempo dos lugares", como se refere Barbosa, ${ }^{20}$ ou seja, o tempo vivido em cada localidade, o qual é composto por um conjunto de experiências distintas num mesmo momento histórico. Como quando Mussolini propagou a campanha contra a maçonaria, no início dos anos de 1920, as lojas italianas em São Paulo decidiram expurgar os membros que eram fascistas. Contudo, em cidades do interior, como Araraquara, a questão maçonaria-fascismo não teve a mesma repercussão. No transcorrer dos conflitos em São Paulo, a rotina das lojas maçônicas do interior permaneceu na normalidade, como se ali os acontecimentos ocorressem à margem da história.

Como já mencionado, a SIU estava situada em Araraquara. Esta cidade está localizada no centro-norte do estado de Sáo Paulo, a 280 km da capital. Sua fundação ocorreu por volta dos anos de 17901795 e ela foi elevada à condição de cidade em fevereiro de 1889. À semelhança de outros municípios, Araraquara cresceu graças à riqueza produzida pela cafeicultura e, para tal, recebeu um número considerável de imigrantes: em 1877, por exemplo, ela estava entre os 21 municípios que receberam mais de mil imigrantes. Segundo o "Recenseamento de Araraquara de 1902", que listou todos (ou quase todos) os indivíduos que habitavam no meio urbano, os italianos representavam 37,\% dos habitantes, $81,1 \%$ em relação aos nacionais e $68,9 \%$ em relação aos estrangeiros. Todavia, a estrutura pela qual ela foi de-

\footnotetext{
${ }^{18}$ É oportuno ressaltar que todas as traduções do italiano para o português, que constam deste artigo, foram feitas pela autora.

${ }^{19}$ MARTINS, José de Souza. Subúrbio. Vida cotidiana e história no subúrbio da cidade de São Paulo, op. cit., p. 20.

${ }^{20}$ BARBOSA, Agnaldo de Sousa. A propósito de um estatuto para a história local e regional: algumas reflexóes. História \& Perspectivas, Uberlândia, v. 20-21, p. 117-128, 1999.
} 
senvolvida calcou-se num contexto de prevalências de poder, encabeçado pelos "coronéis", os quais participavam ativamente da vida política local dominando os órgáos administrativos e absorvendo todas as suas funçôes. Inseridos neste contexto estavam os imigrantes italianos, que tiveram que se adaptar a uma sociedade hostil e relativamente fechada; suas inserçôes na sociedade local foram conquistadas gradualmente. Já a inserção política, o modo alternativo encontrado por alguns foi o de participar da loja maçônica local.

Feitas, portanto, as devidas consideraçóes, podemos agora iniciar as partes essenciais.

\section{Società Italiani Uniti: um panorama de suas funçóes}

A SIU foi fundada em 5 de outubro de 1901, sob denominação de Società Italiana di Beneficenza, posteriormente modificada, quando de sua fusão com a Società Italiana di Mutuo Soccorso, em 15 de novembro de 1920, por influência do ex-ministro italiano Vittorio Emanuele Orlando. Ela se caracterizava como uma associação de beneficência. Todavia, seu espaço era partilhado, ${ }^{21}$ pois, ao mesmo tempo, funcionava como centro de filiação ao Fascio italiano all'estero, cuja sessão se intitulava "Santino Calvi”, ${ }^{22}$ o qual, já em 1932, foi reconhecido como um dos mais importantes centros do Partido Nacional Fascista. ${ }^{23}$ Giuseppe Aufiero era o seu secretário em Araraquara, inclusive, por coincidência (ou não), ele assumiu a presidência da $\mathrm{SIU}^{24}$ no mesmo ano em que foi fundado o primeiro Fascio em Sáo Paulo, em 1923.

A SIU também era permeada pela maçonaria; 29 integrantes dela participavam da loja maçônica local. ${ }^{25}$ Além disso, ela era defensora obstinada do nacionalismo ${ }^{26}$ e da italianidade. ${ }^{27}$ Como se não bastasse, Pisani ${ }^{28}$ constatou que, em 1937, em sua sede social também funcionava a Agência Consular, cujo titular era o sócio Gaspare Abritta. Quanto ao número de sócios, a tabela abaixo, apesar de incompleta, nos permite ter uma noção:

\footnotetext{
${ }^{21}$ Documentos comprovam que em 1928 a SIU já era conhecida como o que denominei de espaço partilhado.

22 PISANI, Salvatore. Lo Stato di San Paolo nel cinquantenario dell'Immigrazione. São Paulo: s.n., 1937. p. 480.

${ }^{23}$ TRENTO, Angelo. Do outro lado do Atlântico, op. cit. p. 310. Partido Nacional Fascista, doravante PNF.

${ }^{24}$ Ele foi presidente da SIU, ininterruptamente, até o seu fechamento em 1941.

${ }^{25}$ Como já assinalado, em cidades do interior paulista como Araraquara, cuja inserção dos imigrantes ocorreu num contexto de prevalências de poder, fazer parte da Loja maçônica era um modo alternativo de participar dos "bastidores" da política local. Todavia, é importante ressaltar que esse era um caso isolado. No decorrer do trabalho foi possível asseverar que tudo estava intrinsecamente relacionado às condiçóes locais de cada colônia italiana. Em Catanduva, cidade localizada a $130 \mathrm{~km}$ de Araraquara, por exemplo, cuja fundaçáo e desenvolvimento ocorreram simultaneamente com a chegada dos imigrantes, havia maior permeabilidade de inserção tanto social como política.

${ }^{26} \mathrm{O}$ fenômeno do nacionalismo ocorre entre pessoas que talvez nunca se encontrem, mas se consideram unidas por um sentimento único de pertença e lealdade.

${ }^{27} \mathrm{~A}$ italianidade nos remete à identidade étnica e, por isso, é um conceito aberto no sentido de que a identidade étnica pode conviver com outras identidades, com outras lealdades, tais como: familiares, regionais, religiosas, políticas, de classe.

${ }^{28}$ PISANI, Salvatore. Lo Stato di San Paolo nel cinquantenario dell'Immigrazione, op. cit. p. 481.
} 
Tabela 1

Società Italiani Uniti: número de sócios

\begin{tabular}{cc}
\hline Anos & № Sócios \\
\hline 1920 & $*$ \\
\hline 1921 & 162 \\
\hline $1922-1926$ & $*$ \\
\hline 1927 & 138 \\
\hline 1928 & 125 \\
\hline $1929-1939$ & $* *$ \\
\hline 1940 & 60 \\
\hline
\end{tabular}

Fontes: Fundação Sistema Estadual de Dados (Seade-SP), Anuários Estatísticos do Estado de São Paulo.

Notas:

*Aparece nos registros dos anuários, porém, não constam os dados.

**Não há exemplares.

Compilado pela autora.

Nota-se que, apesar da junção das duas associaçóes, a SIU era uma instituição de pequeno porte, aglutinando somente uma parcela exígua da comunidade italiana, a qual, segundo o recenseamento realizado pelo IBGE no município de Araraquara no ano de 1920, totalizava 5.775 italianos, dos quais 3.186 eram do sexo masculino.

Ao contrário de sua antecessora, a sua atenção principal não estava propriamente ancorada na funcionalidade da beneficência, em vista das necessidades materiais dos imigrantes, mas de conduzi-los a uma mesma forma de identidade: a nacional. Desse modo, o primeiro passo a ser dado era o de defender a língua, sobretudo educar "italianamente" os filhos dos imigrantes (não somente eles, mas indiretamente os pais). A esse respeito, convém sublinhar, como argumenta Anderson, ${ }^{29}$ que "a característica mais importante das línguas é a capacidade que [elas] têm de gerar comunidades imaginadas, construindo, efetivamente, solidariedades particulares". Portanto, para isso, a SIU tinha a preocupação em manter uma escola de língua italiana.

A Escola Regina Elena de Araraquara, fundada há quatro anos, cumpre uma obra admirável de difusão da nossa língua e, entre os responsáveis por tal empreendimento, destacamos o Dr. Aufiero (...). A partir de hoje, ela terá a contribuição e o incentivo da professora Sra. Norina Troletti Perez. ${ }^{30}$

Do mesmo modo, a SIU mantinha uma biblioteca e uma sala de leitura em sua própria sede, onde poderiam ser encontrados, além de farta bibliografia italiana, jornais italianos publicados no Brasil, dentre eles, o Fanfulla.

Ao mesmo tempo, tornava-se necessário valorizar a colônia, dando-lhes dignidade individual e coletiva. Contudo, isso dependia de como ela mobilizava suas funçóes, as quais reuni sob a denominação de construir, defender e fortalecer a italianidade no seio da colônia italiana. E tudo era feito no sentido de ter sempre uma colônia unida, coesa; quanto mais coesáo tivesse a colônia, mais capacidade de pressão sobre a sociedade local, assim como maior a identificação da italianidade com o fascismo.

\footnotetext{
${ }^{29}$ ANDERSON, Benedict. Comunidades imaginadas. Reflexôes sobre a origem e a expansão do nacionalismo. Lisboa: Edições 70, 2005. p. 176.

${ }^{30}$ BIBLIOTECA NACIONAL DO RIO DE JANEIRO. Jornal Il Piccolo, 25 out. 1925.
} 
Os imigrantes que se inseriam na SIU eram envolvidos por imagens, uma vez que suas paredes eram repletas de retratos de heróis nacionais. Essas imagens, certamente, proporcionavam-lhes os meios de ação da "imaginação nacional", ${ }^{31}$ pois ao "produzir sentidos sobre a 'nação', sentidos com os quais [eles poderiam se] identificar, [construíam-lhes] identidades". ${ }^{2}$

Eram nas comemoraçóes de datas cívicas italianas que os afiliados da SIU evocavam a "comunidade imaginada" e durante as mesmas a italianidade chegava ao seu ponto de esplendor. Essas datas, geralmente, eram comemoradas com bailes musicais, os quais incluíam hinos patrióticos, exaltação patriótica e inflamados discursos. Segundo seu secretário, elas faziam parte do programa para manter sempre vivo o sentimento de italianidade na colônia de Araraquara. ${ }^{33}$

\section{Società Italiani Uniti}

A laboriosa colônia italiana, desta localidade, realizou na sede social, cujo suntuoso edifício se vê ereto à av. Portugal, desta cidade, e ainda em construção, o anunciado sarau dançante, em comemoração à gloriosa data - XX de Setembro. ${ }^{34}$ (...) A festividade, que se revestiu do maior entusiasmo e abrilhantada pela excelente corporação musical "Carlos Gomes", terminou o seu ato comemorativo às 24 horas do referido XX de Setembro. ${ }^{35}$

Igualmente, por questóes de caráter patriótico, a diretoria da SIU ativava seu "imaginário nacionalista" ${ }^{36}$ transformando-se em canal de mobilização popular, como ocorreu na ocasiáo da morte do aviador italiano Carlo Del Prete, falecido no Rio de Janeiro. Ele foi homenageado com uma placa em seu nome colocada no pátio da sede, com todas as honras de herói e na presença não só da colônia italiana, mas da população araraquarense. ${ }^{37}$

A SIU também funcionava como espaço de sociabilidade promovendo espetáculos teatrais e musicais, projeção de filmes, quermesses, conferências, jogos de futebol etc. Nesses eventos, a "comunidade imaginada" era evocada por meio de exibiçóes que giravam sempre em torno de temas italianos:

Conforme noticiamos, a Sociedade Italiani Uniti fez exibir ontem no Cine Central o filme "Voo Orbetello Rio", constituindo esse elegante espetáculo uma verdadeira apoteose dedicada à laboriosa colônia italiana aqui domiciliada. A casa, que estava cheia tanto na $1^{a}$ como na $2^{\underline{a}}$ sessão, apresentava os maiores vultos da colônia amiga, assim como as mais representativas personagens do nosso "cast" social. ${ }^{38}$

De fato, a influência nacionalista é inegável. Quanto à função da beneficência, ela auxiliava seus sócios, reconhecidos como necessitados, com um fundo oriundo de uma porcentagem das contribuiçóes mensais. Ademais, a SIU atuava com fins filantrópicos, fazendo doaçôes expressivas que eram anunciadas pela imprensa local e que lhe davam respeitabilidade.

\footnotetext{
${ }^{31}$ ANDERSON, Benedict. Comunidades imaginadas, op. cit. p. 51.

${ }^{32}$ HALL, Stuart. A identidade cultural na pós-modernidade. Tradução de Tomaz Tadeu da Silva e Guacira Lopes Louro.

8. ed. Rio de Janeiro: DP\&A, 2003. p. 51.

33 SIU, Livro de Atas, 15 fev. 1936, p. 228.

${ }^{34}$ Data em que se comemora a anexação de Roma ao Reino da Itália, que ocorreu em 1870.

${ }^{35}$ ARQUIVO PÚBLICO HISTÓRICO RODOLPHO TELAROLLI. Jornal Gazeta do Povo, Araraquara, 23 set. 1925. Náo paginado.

${ }^{36}$ ANDERSON, Benedict. Comunidades imaginadas, op. cit. p. 228.

${ }^{37}$ SIU, Livro de Atas, 18 ago. 1928.

${ }^{38}$ ARQUIVO PÚBLICO HISTÓRICO RODOLPHO TELAROLLI. Jornal O Imparcial, Araraquara, 15 jan. 1932.
} 


\section{Anos de 1920: primeiro Estatuto}

\section{Regras}

Em seu primeiro Estatuto, a SIU tinha como objetivo a união, a instrução, a educação moral e a beneficência entre os italianos. Ela também se propunha manter e desenvolver o sentimento de italianidade e o espírito de fraternidade entre os compatriotas. ${ }^{39}$

Poderiam ser sócios apenas aqueles que tivessem bons costumes e reputação ilibada, que estivessem pelo menos há seis meses no município de Araraquara e que tivessem de 18 a 50 anos de idade. Do mesmo modo, poderiam ser admitidos sócios com idades mais avançadas; estes, porém, não tinham direito à beneficência. Os sócios eram divididos em cinco categorias: a) "fundadores" eram aqueles que faziam parte das duas associaçôes na ocasião da fusão; b) "perpétuos" eram aqueles que, na condição de efetivos, pagassem uma contribuição de 300 mil réis no ato da admissão, permanecendo isentos de contribuição mensal; c) "beneméritos" eram aqueles que, independentemente da nacionalidade, contribuíssem com uma cota não inferior a quinhentos réis, caso o conselho reconhecesse o merecimento; d) sócios "honorários" eram aquelas pessoas que, propostas pelo conselho, fossem dignas em virtude dos grandes serviços materiais ou morais que tivessem sido prestados aos patrícios, à Itália ou à humanidade; e) os sócios "efetivos" eram todos os cidadãos italianos, oriundos da província italiana ou filhos de pais italianos. Aos sócios beneméritos e honorários apenas cabia o direito de assistir às conferências e às festas da SIU, não podiam discutir nem votar na assembleia. A admissão dos sócios efetivos e perpétuos era de competência da diretoria que, reunida em sessão, obedecia as seguintes formalidades: o candidato a fazer parte da SIU deveria apresentar pedido por escrito, firmado por dois sócios e pelo proponente indicando nome, sobrenome, filiação, idade, profissão, estado civil e local de nascimento; o pedido era fixado num quadro da sala social por oito dias seguidos e era favoravelmente aceito se não houvesse oposição por parte de um ou mais sócios. Em caso de oposição, o conselho deliberava com o voto secreto e, rejeitada a admissão, ele não era obrigado a dizer as razóes pelas quais havia sido recusado o pedido. ${ }^{40}$

Em relação às assembleias, elas se dividiam em ordinárias e extraordinárias. As assembleias gerais ordinárias ocorriam no primeiro sábado de janeiro, primeiro sábado de abril, primeiro sábado de julho, primeiro sábado de outubro e no primeiro domingo de dezembro. Nelas, eram discutidas e passadas por aprovação as gestóes tanto financeiras como do ponto de vista moral das atividades que haviam sido desenvolvidas pela associação. Por sua vez, as assembleias gerais extraordinárias poderiam ser convocadas pelo presidente, pelo conselho ou quando a quarta parte dos sócios achasse necessária sua convocação. Durante a existência da SIU foram convocadas quatorze assembleias extraordinárias, cinco delas quando ocorreu a fusão em 1920 e as outras distribuídas, sobretudo, no período referente a esse Estatuto (1921-1930).

O capítulo do Estatuto que tratava da beneficência rezava que a associação teria um fundo social, que seria formado pela prevalência de vinte por cento sobre as contribuiçóes mensais, para auxiliar os sócios reconhecidos como necessitados em casos de doença, desgraça ou morte. Para que os sócios fossem socorridos, estes teriam que fazer um pedido verbal, por escrito ou por meio de um sócio. $\mathrm{O}$ Conselho Diretor, tomando conhecimento de tal necessidade, decidiria qual o socorro poderia prestar, de acordo com a necessidade do sócio e com os fundos sociais, pelos quais a associaçáa poderia dispor na ocasião.

Em outro capítulo, a língua oficial a ser adotada era a italiana. Além disso, a associação deveria conservar-se afastada de qualquer questão política, respeitando todas as crenças, opinióes e contribuiçôes com todos os esforços para o progresso humano. E o seu último artigo rezava que a associação con-

\footnotetext{
${ }^{39}$ SIU, Livro de Atas, 12 mar. 1921, p. 41.

${ }^{40}$ SIU, Livro de Atas, 12 mar. 1921, p. 42-44.
} 
tinuaria a existir até que tivesse sete sócios. Vindo a faltar um, seria considerada encerrada e os fundos sociais seriam encaminhados em benefício de um trabalhador italiano.

\section{Eventos}

A meta da associação no período do primeiro Estatuto foi a construção da sede social, cuja inauguração ocorreu no dia 8 de fevereiro de $1926 .{ }^{41}$ Neste ano, devido aos gastos com o grande empreendimento, as finanças da associação estavam em baixa e os ânimos dos sócios estavam alterados. Duas assembleias extraordinárias foram convocadas. A primeira, no dia 16 de janeiro, foi convocada por meio de uma carta firmada por uma comissão composta por oito sócios. Eles protestavam contra a deliberação da assembleia do dia 2 de janeiro, que elevou a taxa de admissão de 10 mil réis para 50 mil réis e a mensalidade de 5 mil réis para 10 mil réis, em prol da construção da nova sede. Em meio a inflamadas discussóes, ficou estabelecido fazer uma nova votação.

O assunto foi posto em votação e resultou no seguinte: 31 sócios aprovaram os aumentos, 45 foram contra e houve seis abstençóes. Em vista do resultado, tanto a taxa de admissão quanto a mensalidade não sofreram aumentos. Contudo, o resultado náo bastou para conter a desarmonia entre os sócios. Em assembleia extraordinária, realizada no dia 2 de junho de 1926, a segunda daquele ano, o sócio dr. Domenico Gatto fez uma grave observação:

Senhores! Em qualquer dia na cidade, e precisamente nos cantos, fala-se da Italiani Uniti de tal forma que parece que os sócios que a compóem se encontram em completo desacordo; que a associação é mensageira do caos e, se não bastasse, as pessoas que estão falando isso dos sócios são brasileiros e estrangeiros. Isso é uma inconveniência e prejudica o prestígio privado de todos nós. Devemos estar convictos que o único expoente da colônia italiana desta cidade é a nossa associação. Temos a obrigação de evitar, por qualquer razão, que falem mal e tomar as providências necessárias para evitar fazer a formação de grupos dissidentes na praça e, quando houver, vamos modificar o procedimento de criticar em sociedade. ${ }^{42}$

É claro que essas dissidências abalavam não apenas a associação como instituição, mas diretamente os seus componentes, que queriam manter uma performance de união perante a sociedade local. Um indício dessas desavenças já poderia ser vislumbrado desde a assembleia ordinária do dia 2 de janeiro do referido ano, como já mencionado, prolongando-se também na assembleia ordinária ocorrida em 10 de abril. Nessa, dois grupos (um maior e outro menor) de sócios se enfrentaram verbalmente. Com isso, ficou visível a existência de duas facçôes no interior da SIU, que provavelmente se distinguiam de acordo com suas posses materiais. Para se dar uma ideia, nessa mesma assembleia, com o intuito de compensar a derrota daqueles que queriam os aumentos, foi realizada uma subscrição entre os sócios e arrecadaram-se um conto e 970 mil-réis. Ela teve início com a subscrição do sócio Antonio Barra, no valor de 500 mil-réis. Nesse sentido, é razoável pensar que, quanto mais as identidades étnicas estiverem ligadas a fatores diferenciais de ordem econômica, menos permeáveis são as fronteiras entre os grupos. ${ }^{43}$ Ainda é relevante ressaltar que boa parte dos membros da SIU conseguiu se destacar tanto financeira como socialmente e esses desentendimentos podem sugerir, sobretudo, que a ascensão social de alguns se expressa nos conflitos internos da SIU.

\footnotetext{
${ }^{41}$ Pisani assinala que a sede social da SIU era "luxuosa e imponente" e estava classificada entre as melhores do exterior. É oportuno ressaltar que esse prédio (situado à av. Portugal, n. 8) foi construído no terreno adquirido pela Società Italiana di Beneficenza, anteriormente mencionada, em 1909, e media $240 \mathrm{~m}^{2}$ (PISANI, Salvatore. Lo Stato di San Paolo nel cinquantenario dell'Immigrazione, op. cit. p. 480).

42 SIU, Livro de Atas, 2 jun. 1926, p. 128.

${ }^{43}$ POUTGNART, Philippe; STREIFF-FENART, Jocelyne. Teorias da etnicidade. Seguido de Grupos étnicos e suas fronteiras de Fredrik Barth. Tradução de Elcio Fernandes. São Paulo: Fundação Editora da Unesp, 1998. p. 155.
} 
De modo geral, os anos 1920, início da SIU, caracterizaram-se como um tempo produtivo tanto financeiramente como de prestígio para os membros dirigentes e também para a associação. Eles conseguiram cumprir sua meta principal, como visto, a construção da sede social. Também cumpriram outras metas mais gerais, tais como: a compra da mobília para a sede, um telefone, um piano, amplo espaço para jogos, uma diversificada biblioteca etc. Enfim, foram anos de grandes realizaçóes. Além disso, é relevante destacar que as visitas das autoridades consulares foram tão frequentes no período do primeiro Estatuto quanto no do segundo. ${ }^{44}$

\section{Anos de 1930: segundo Estatuto}

\section{Regras}

A partir dos anos 1930, a definição e a execução dos objetivos sociais alteraram-se. A reformulação do Estatuto social demonstra a preocupação por valores do grupo e princípios morais baseados, acima de tudo, num sentimento de italianidade e de amor à pátria distante.

O segundo Estatuto da SIU foi aprovado em junho de 1931. Agora bem mais ampliado, o mesmo trazia diversas modificaçôes, entre elas: a extinção da categoria de sócio "perpétuo", permanecendo apenas as outras, mas com algumas modificaçôes; as taxas de admissão foram fixadas em 20 mil-réis e as mensalidades em 5 mil-réis; houve alteração no número de cargos dirigentes; as assembleias gerais ocorriam, agora, no primeiro sábado de janeiro, no segundo sábado de julho, no último sábado do mês de novembro e no segundo domingo de dezembro; desse modo, de cinco sessóes por ano passou a ter apenas quatro; também ficou extinta a assembleia de terceira convocação; a língua oficial permaneceria a italiana, mas em razão da autoridade local e com a terça parte do Conselho Diretor seria autorizada a fazer uso da língua portuguesa. Em compensação, aumentou a importância que o Conselho Diretor poderia reter para beneficência, que no primeiro Estatuto era de vinte por cento e neste seria de 25 por cento.

Quanto à duração da associação, esta seria ilimitada até que o número de sócios fundadores se reduzisse a seis componentes, sendo entáo extinta. Contudo, diferente do primeiro Estatuto, seu patrimônio passaria a ser de propriedade absoluta do Reino da Itália, o que demonstra declaradamente o seu forte vínculo com o governo italiano. Nessa fase, a associação já havia constituído um considerável patrimônio. É interessante destacar que esse Estatuto só poderia ser modificado com a deliberação unânime da assembleia geral dos sócios, depois de ter obtido a "preventiva" aprovação do governo da Itália representado pelo cônsul responsável pela zona de Araraquara..$^{45}$

\section{Eventos}

O que chama a atenção nesse período é o reduzido número de sócios que participavam das assembleias, em relação ao período anterior, que tinha uma média de participação em torno de 65 sócios. Para se dar uma ideia, em 1937, de acordo com Pisani ${ }^{46}$ os italianos residentes no município de Araraquara giravam em torno de 8 mil e seus filhos em aproximadamente 13 mil, o que mostra uma diferença extremamente grande em relação ao mesmo ano no quadro a seguir.

\footnotetext{
${ }^{44} \mathrm{Na}$ verdade, as visitas às colônias italianas localizadas no interior eram uma prática comum das autoridades diplomáticas italianas, com o propósito de fazer campanhas a favor do fascismo. Cervo assinala que o embaixador Montagna, que frequentemente viajava para o interior de São Paulo, com o intuito de assegurar algum êxito para sua ação de propaganda, “procurou difundir o 'grande conceito' do fascismo, ligado à ordem, à eficiência, ao progresso, à solidariedade de classe, à coesão espiritual e moral”. CERVO, Amado Luiz. As relaçóes históricas entre o Brasil e a Itália: o papel da diplomacia. Brasília: Editora Universidade de Brasília; São Paulo: Istituto Italiano di Cultura, 1992. p. 100.

${ }^{45}$ SIU, Livro de Atas, Artigo 57, 6 jun. 1931, p. 196.

${ }^{46}$ PISANI, Salvatore. Lo Stato di San Paolo nel cinquantenario dell'Immigrazione, op. cit. p. 479.
} 
Quadro 1

Participação dos sócios nas Assembleias, 1931-1937

\begin{tabular}{lc}
\hline \multicolumn{1}{c}{ Mês/Ano } & $\begin{array}{c}\text { № } \\
\text { Sócios }\end{array}$ \\
\hline Jan. 1931 & 46 \\
\hline Jun. 1931 & 46 \\
\hline Jul. 1931 & 23 \\
\hline Out. 1931 & 19 \\
\hline Dez. 1931 & 34 \\
\hline Jan. 1932 & 27 \\
\hline Dez. 1932 & 25 \\
\hline Dez. 1932 & 27 \\
\hline Jan. 1933 & 22 \\
\hline Nov. 1933 & 20 \\
\hline Dez. 1933 & 30 \\
\hline
\end{tabular}

\begin{tabular}{ll}
\hline \multicolumn{1}{c}{ Mês/Ano } & № Sócios \\
\hline Fev. 1934 & 26 \\
\hline Nov.1934 & 23 \\
\hline Dez. 1934 & 40 \\
\hline Fev. 1935 & 16 \\
\hline Nov. 1935 & 20 \\
\hline Dez. 1935 & 21 \\
\hline Fev. 1936 & 21 \\
\hline Nov. 1936 & 17 \\
\hline Dez. 1936 & 26 \\
\hline Jan. 1937 & 22 \\
\hline Dez. 1937 & 23 \\
\hline
\end{tabular}

Fonte: SIU, Livro de Atas, diversas páginas.

De fato, o declínio nas participaçóes dos sócios é inegável. Pode-se supor, entretanto, que uma das causas desses decréscimos possa ser fruto de uma geração de sócios que começou a envelhecer, adoecer e/ou falecer. As outras podem estar relacionadas à provável expulsão de elementos não desejáveis no âmbito da associação, os quais, mesmo não compartilhando das ideias fascistas, frequentavam a associação (suspeita-se também da infiltração de antifascistas); ${ }^{47}$ e/ou ao afastamento dos sócios que consideravam a SIU não como um instrumento de difusão das ideias fascistas, já que as assembleias eram repletas de retórica nacionalista, mas funcionalmente como um espaço de sociabilidade entre os italianos; e/ou a falta de interesse de ingresso de novos sócios, já que, como vimos, o número de italianos e descendentes no município era substancial. Outra possibilidade é o não envolvimento com uma associação fascista.

Todavia, a redução de sócios nas reuniôes das assembleias já era consequência da diminuição no quadro social. Nesse sentido, vale a pena notar que há um paradoxo entre o que estava ocorrendo no seio da SIU e a grande virada fascista dos anos 1930. Como bem assinala Trento, "no seio da coletividade italiana, os anos 30 representaram uma reviravolta na popularidade do regime (...) os anos 30 infundiram nos italianos um maior orgulho pelas realizaçóes internas e êxitos internacionais da mãe-pátria”. ${ }^{48}$ Uma compreensão que parece plausível pode estar ancorada ao modo como Araújo ${ }^{49}$ amplia

\footnotetext{
${ }^{47}$ Alguns meses antes das eleiçóes do ano de 1930, gestão 1931, um artigo publicado no jornal La Difesa questionava, em tom ofensivo, o presidente da SIU, Giuseppe Aufiero (1923-1941), pelo modo com o qual ele conduzia a administração da associação. Já bem próximo das eleiçóes, um jornal local publicou uma nota na qual pedia aos associados que votassem em determinados membros para formar uma nova diretoria e nomear Giuseppe Aufiero como sócio "honorário”, por aclamação. Uma maneira explícita de afastar Aufiero da presidência da SIU, já que essa categoria, como visto, não dava direito ao sócio de discutir e nem de votar nas assembleias. Tudo leva a crer que se tratava da ação de antifascistas, infiltrados na associação, contra fascistas, em que os primeiros tentavam desacreditar particularmente o presidente da SIU, justamente porque ele era o representante do Fascio local. Todavia, a tentativa foi frustrada. Esse episódio resultou na expulsão de sócios. ${ }^{48}$ TRENTO, Angelo. Do outro lado do Atlântico, op. cit. p. 338-339.

${ }^{49}$ ARAÚJO, José Renato de Campos. Migna Terra. Migrantes italianos e fascismo na cidade de São Paulo (1922/1935). Tese (doutorado em ciências sociais) — Instituto de Filosofia e Ciências Humanas, Universidade Estadual de Campinas, Campinas, 2003.
} 
o conceito de "fascismo difuso", criado por Bertonha ${ }^{50}$ para definir o grau de adesão ao regime fascista e medir a eficácia de sua propaganda em solo paulistano, abrindo espaço para a etnicidade. Na verdade, ele relaciona o "fascismo difuso" a sentimentos étnicos. Segundo Araújo,

A positividade conferida pela imagem internacional da Itália nada tinha a ver com a complexa conversão ideológica ao fascismo, ${ }^{51}$ sendo encarada como trunfo no jogo simbólico dentro de uma sociedade multiétnica como a paulistana (...). O fascismo difuso emergiria a partir da positividade que essa imagem concederia ao migrante em seu relacionamento societário cotidiano num ambiente social onde ser étnico era uma característica importante. (...) O fascismo difuso no Brasil (...) foi um fenômeno gerador de muito sentido no seio do grupo migrante em suas relaçóes sociais no interior da sociedade receptora, mas que quase nenhum sentido gerou quando pensamos numa ligação mais orgânica com o regime fascista e até mesmo com a própria Itália. Afirmamos que esse tipo peculiar de filiação tinha muito mais elementos étnicos do que ideológicos para o grupo migrante, visto que essa adesão o transformava, pela primeira vez na sua trajetória, numa comunidade imaginada baseada no sentimento de pertença e que, por sua vez, alicerçava-se numa origem comum aos indivíduos que a compunham..$^{52}$

De fato, embora o fascismo tenha dado uma conotação ideológica à construção de uma identidade nacional, ${ }^{53}$ concordo com Araújo que, para o imigrante, o "fascismo difuso" era mais dotado de elementos étnicos do que ideológicos, visto que, como ele mesmo notou, no Brasil da década de 1930, "a assimilação assumia características especiais, posto que o governo brasileiro entendia esse processo como saudável para uma jovem nação que forjava seu espírito nacional". ${ }^{4}{ }^{4}$

As autoridades brasileiras começavam a ver com muito bons olhos o relacionamento com grupos de "origens étnicas" fundadas em nações que se apresentavam como vanguardas da modernidade e pilares da civilização ocidental, já que para essas autoridades, a assimilação seria a maneira de o povo brasileiro incorporar as "qualidades" morais e culturais dos grupos estrangeiros fixados no território. ${ }^{55}$

Retomando, a diminuição do quadro social começou a refletir economicamente, pois na assembleia de janeiro de 1933 o tesoureiro apresentou o balanço anual com um alto débito que precisaria ser saldado. Diversas propostas foram apresentadas para tentar solucionar o problema; entre elas, foi aprovada a do sr. Rômulo Lupo, que tinha como objetivo a admissáo de sócios numa nova modalidade, a de "frequentadores". Essa proposta, além de abrir espaço para indivíduos de outras nacionalidades, contava com uma contribuição mensal de 5 mil-réis. Era imprescindível, contudo, que o candidato a sócio nutrisse um sentimento de simpatia pela Itália. Assim, foi estabelecida uma norma geral para tais sócios, cujo conteúdo incluía, por exemplo, que eles não poderiam votar e nem serem votados, assim como era

\footnotetext{
${ }^{50}$ BERTONHA, João Fábio. Sob o signo do fascio, op. cit.

${ }^{51}$ Convém assinalar que Bertonha entende que não houve uma conversão ideológica total dos imigrantes italianos ao fascismo, relativizando-a a uma simpatia ao regime (ibid.).

${ }^{52}$ ARAÚJO, José Renato de Campos. Migna Terra, op. cit. p. 241-243.

${ }^{53}$ TRENTO, Angelo. I fasci in Brasile. In: FRANZINA, Emilio; SANFILIPPO, Matteo (A cura di). Il fascismo e gli emigrati. La parabola dei Fasci italiani all'estero (1920-1943). Roma: Laterza, 2003. p. 152-166. Contudo, segundo Trento, ele náo alcançou o objetivo de doutrinar ideologicamente os italianos no Brasil. TRENTO, Angelo. Il Brasile, gli immigrati e il fenomeno fascista. In: BLENGINO, Vanni; FRANZINA, Emilio; PEPE, Adolfo. La riscoperta delle Americhe. Lavoratori e sindicato nell'emigrazione italiana in America Latina 1870-1970. Atti del Convegno Storico Internazionale promosso dalla Camera del Lavoro Territoriale/Cgil di Brescia: Brescia, 25/26/27 nov. 1992. Milano: Nicola Teti Editore, 1994 , p. 251.

${ }^{54}$ ARAÚJO, José Renato de Campos. Migna Terra, op. cit. p. 242.

${ }^{55}$ Ibid.
} 
expressamente proibido fazer propaganda ou discutir política na sede social. Os sócios "frequentadores" também deveriam permanecer completamente alheios à direção da Società, de forma que esta pudesse manter sempre intactos os princípios de italianidade. Além da aprovação da modalidade de sócios "frequentadores", foi proposta a readmissão dos sócios acometidos por doença ou falta de trabalho, os quais poderiam começar a pagar a partir do mês de janeiro. E ainda para dar um bom resultado, o Conselho propôs a formação de uma comissão para fazer propaganda entre os italianos de Araraquara.

$\mathrm{Na}$ assembleia geral de novembro desse ano de 1933, o presidente se congratulou com os componentes do Conselho por terem obtido melhores condiçóes financeiras e, do mesmo modo, liquidado o débito da associação (não está registrado, mas suspeito que essa melhora nas finanças tenha ocorrido devido às frequentes subscrições entre os sócios e não por um aumento substancial no quadro social). Nos anos posteriores, a associação conseguiu manter um saldo positivo, mesmo com um número de sócios sempre limitado. De fato, a questão dos sócios ainda se constituía um problema. Ainda nessa mesma assembleia, o sócio, dr. Granata, manifestou o desejo de reunir o maior número possível de afiliados em assembleia extraordinária, para saber deles os meses mais oportunos para frequentar a SIU, a fim de desenvolver maior propaganda de italianidade. A resposta dos conselheiros foi a seguinte:

O Conselho já se ocupou com essa questão e, a saber, não é nova e nem de fácil atuação, pelo contrário. Para seu conhecimento, já foi deliberado pelo Conselho conceder a permissão para frequentar a Società diversos ex-sócios que não podiam mais pagar as respectivas mensalidades e iniciar uma nova campanha dos sócios abolindo a taxa de admissão até 30 de janeiro próximo, para facilitar a entrada. Todavia, o que se viu foi uma apatia total da colônia local. ${ }^{56}$

De qualquer forma, para elevar-se diante da colônia italiana, a SIU se utilizou da funcionalidade da beneficência, inaugurando em sua sede um consultório com atendimento médico gratuito aos mais carentes.

\section{Consultório médico gratuito da Società Italiani Uniti}

Comunica-nos à Diretoria da Sociedade Italiana, que se acha funcionando o seu "Ambulatório Médico Gratuito", e que nos diversos dias da semana, e das 14 às 15 horas, se acham de plantáo os seguintes médicos: $2^{\underline{a}}$ feira, dr. G. Aufiero; $3^{\underline{a}}$ feira, dr. R. Mauro; $4^{\mathrm{a}}$ feira, dr. G. Granata; $5^{\underline{a}}$ feira, dr. F.L. Lombardi, (pediatra); 6 ${ }^{a}$ feira, dr. A. Cariani e sábado, dr. Aufiero Sobrinho. ${ }^{57}$

Infelizmente as atas não registram se houve ou não resultado positivo para SIU.

Nos anos em que decorreu o segundo Estatuto, as questóes norteadoras das reunióes se pautaram em ressaltar o sentimento de italianidade, que fervilhava nas comemoraçóes de datas históricas italianas, como vimos, e nas recepçóes às autoridades consulares e aos membros do Fascio. Nos registros das atas desse período, parece que há a necessidade de mostrar, por um lado, que a SIU era o Fascio e, por outro, que o Fascio era a SIU. Os trechos a seguir, extraídos respectivamente das Aassembleias dos meses de fevereiro de 1934 e de 1935, nos permitem entender, com mais clareza, os laços que a SIU mantinha com o Fascio:

\footnotetext{
${ }^{56}$ SIU, Livro de Atas, 29 nov. 1936, p. 232.

${ }^{57}$ ARQUIVO PÚBLICO HISTÓRICO RODOLPHO TELAROLLI. Jornal O Diário, Araraquara, 29 fev. 1932. Não paginado.
} 
A Società e o Fascio, que vivem na mais completa harmonia, têm feito todo o possível para dar uma agradável hospitalidade aos seus ilustres visitantes. (...) Em todas as ocasióes a Società fez o possível para continuar a tradição patriótica desta colônia, seja com a abertura de toda a sua sede, que recebe com fraternal apreço todos aqueles que sentem e pensam italianamente, ou com a propaganda de leitura em jornais e folhetos patrióticos e com a difusáo da biblioteca circulante, oportunamente organizada pelo Fascio, que serve também para os sócios da Società. Dessa forma, queremos manter sempre viva a paixão pela italianidade..$^{58}$

Na medida das nossas forças, e sempre de acordo com o Fascio local, foi comemorada a data histórica da nossa Pátria, com conferência e entretenimento, que despertaram um vivo entusiasmo na grande quantidade dos conacionais que estavam presentes, e também simpatia da parte das autoridades e convidados brasileiros. (...) Para festejar o 28 de outubro, data da Marcha sobre Roma, o Fascio e a nossa Società organizaram um entretenimento para honrar o nosso Cônsul Vecchiotti, com gentil pensamento mandado pelo comissário Salvatore Pisani, que fez brilhante dissertação sobre a data que deu início à Era Fascista. (...) A nossa sede, que é também a do Fascio, constitui verdadeiramente a casa dos italianos e, seja na biblioteca, nas revistas e jornais, no esporte ou seja pelo desejo de viver em ambiente italiano, a nossa sede, geralmente, é frequentada por um bom número de conacionais e amigos que vêm provar da nossa retidão e vontade de fazer o bem. ${ }^{59}$

Portanto, sem sombra de dúvida, no período que compreende o segundo Estatuto, o objetivo fundamental da SIU era o de utilizar as suas funçóes, baseada na ótica do nacionalismo e da italianidade, visando obter um consenso da colônia italiana residente, com o intuito de inculcar a ideologia fascista. No entanto, mesmo que as afirmaçóes a seguir sejam somente conjecturas plausíveis e não verdades demonstráveis, devido à falta de elementos para validá-las, acredito que a ideologia conscientemente defendida pelos seus dirigentes estava longe de ser aceita pela maioria dos sócios e pela grande parte da colônia italiana residente. Isso, claro, porque entendo, assim como Bertonha, ${ }^{60}$ que o consenso ao fascismo não teve uma implicação realmente ideológica.

\section{Terceiro Estatuto (1938-1941)}

\section{Regras}

O terceiro e último Estatuto da SIU foi aprovado em assembleia extraordinária realizada no dia 8 de outubro de 1938. O Estatuto anterior precisou ser reformulado e regularizado para obedecer ao Decreto-Lei de 18 de abril de 1938 publicado oficialmente pelo governo brasileiro, ${ }^{61}$ o qual será explicitado mais adiante. Bem mais reduzido, o novo Estatuto continha apenas 42 artigos, entre eles: o objetivo da SIU seria o de proporcionar aos cidadãos italianos, residentes em Araraquara, e que dela fizessem parte, recreio, instrução e assistência. ${ }^{62}$

Os cargos do Conselho Diretor agora tinham duração de dois anos; as reunióes seriam realizadas uma vez por ano, na primeira quinzena de janeiro; houve redução na administração, que passou a ser constituída por dez membros: um presidente, um vice-presidente, um tesoureiro, um secretário, um administrador, três conselheiros efetivos e dois substitutos; eram considerados sócios apenas os cidadãos

\footnotetext{
${ }^{58}$ SIU, Livro de Atas, 27 fev. 1934, p. 213, 215.

${ }^{59}$ SIU, Livro de Atas, 2 fev. 1935, p. 220-222.

${ }^{60}$ BERTONHA, João Fábio. Sob o signo do fascio, op. cit.

${ }^{61}$ SIU, Livro de Atas, 8 out. 1938, p. 251.

${ }^{62}$ Como já tivemos a oportunidade de enfatizar, os Estatutos vão se adequando "tanto à dinâmica interna do grupo, como para atender às mudanças de conjunturas do Brasil e do regime fascista”.
} 
italianos; a sociedade teria existência ilimitada, todavia, se o número de sócios fosse inferior a sete, os sócios remanescentes teriam a faculdade de dissolver a associação. Neste caso, o patrimônio seria doado ao Hospital Umberto I de Sáo Paulo. Contudo, se ele não mais existisse, tal patrimônio se destinaria a um instituto de beneficência que, na ocasião, seria indicado pelos sócios remanescentes. ${ }^{63}$

\section{Eventos}

A partir dos anos 1930, percebe-se, portanto, que há uma ênfase muito maior nas questóes que relacionavam a SIU ao Fascio. Concomitante a isso, o regime fascista aprofunda suas tendências imperialistas e totalitárias e reforça a ideia de um verdadeiro "Império italiano" no mundo. ${ }^{64}$ Do lado brasileiro, a Revolução de 30 levou ao poder novos atores, sob o comando de Getúlio Dornelles Vargas. A política no Brasil toma outros rumos: moralização da vida pública, expansão das atividades urbanas, ampliação da economia assalariada, expansão das indústrias, reforço da segurança nacional. A proposta brasileira para esse período "comportava uma dose elevada de nacionalismo". E o confronto dos nacionalismos se agravaria ao longo desta década. Assim, "a italianidade deveria ser devorada pela brasilidade, esta era a proposta brasileira, inaceitável obviamente pelo lado oposto". ${ }^{5}$

Ocorre que com a publicação do Decreto-Lei n. 383, que vedava aos estrangeiros a atividade política no Brasil, as associaçóes sofreram uma série de imposiçóes por parte do governo brasileiro.

Art. 1ํ - Os estrangeiros fixados no território nacional e os que nele se acham em caráter temporário não podem exercer qualquer atividade de natureza política nem imiscuir-se, direta ou indiretamente, nos negócios públicos do país. (...)

Art. 2o- É-lhes vedado especialmente:

1 - Organizar, criar ou manter sociedades, fundaçóes, companhias, clubes e quaisquer estabelecimentos de caráter político, ainda que tenham por fim exclusivo a propaganda ou difusão, entre seus compatriotas, de ideias, programas ou normas de ação de partidos políticos do país de origem (...)

Art. 3o- É lícito aos estrangeiros associarem-se para fins culturais, beneficentes ou de assistência, filiarem-se a clubes e quaisquer outros estabelecimentos com o mesmo objeto, bem assim reunirem-se para comemorar suas datas nacionais ou acontecimentos de significação patriótica (...)

Art. $4^{\circ}-$ As proibiçóes contidas nos artigos anteriores alcançam as escolas e outros estabelecimentos educativos mantidos por estrangeiros ou brasileiros, e por sociedades de qualquer natureza, fim, nacionalidade e domicílio.

Art. 5- - Das entidades a que se refere o Art. 3ำ não podem, no entanto, fazer parte: brasileiros, natos ou naturalizados, ainda que filhos de estrangeiros.

Art. 6o - As entidades referidas nos arts. $3^{\circ}$ e $4^{\circ}$ não poderão funcionar sem licença especial e registro concedido pelo Ministério da Justiça e Negócios, na forma do decreto-lei n. 59, de 11 de dezembro de 1937, e do regulamento aprovado pelo decreto n. 2229, de 30 de dezembro de 1937, cujas disposiçóes lhes são aplicáveis. (...)

Art. 8- - O Ministro da Justiça e Negócios Interiores poderá ordenar a interdição das sedes e de todos os locais em que exerçam as atividades que ficam vetadas por esta lei. ${ }^{66}$

\footnotetext{
${ }^{63}$ Note-se que, no primeiro Estatuto, o patrimônio da SIU seria doado em benefício de uma obra italiana e, no segundo, ele passaria a ser de propriedade absoluta do governo da Itália.

${ }^{64}$ BERTONHA, João Fábio. O Brasil, os imigrantes italianos e a política externa fascista, 1922-1943, op. cit. p. 111.

${ }^{65}$ CERVO, Amado Luiz. As relaçóes históricas entre o Brasil e a Itália, op. cit. p. 142.

${ }^{66}$ ARQUIVO DO ESTADO DE SÃO PAULO. Coleção das Leis de 1938. Imprensa Nacional: Rio de Janeiro, 1938. v. II, p. 53-54.
} 
Dias depois da publicação do decreto, precisamente em 26 de abril, em correspondência à Embaixada Italiana no Rio de Janeiro, o ministro degli Affari Esteri" comunicava que a "posição da coletividade [deveria] continuar, por enquanto, como sempre foi, ou seja, selando um espírito de leal colaboraçáo e evitando campanhas e reaçóes que [provocassem] contrarreaçóes e contracampanhas da parte daqueles que [tinham] o comando da situação". ${ }^{68}$ Já em setembro, parte da mensagem de Luigi Lojacono, da Embaixada Italiana do Rio de Janeiro, enviada a Roma, continha a seguinte frase: "É como transformar um quadrado em um círculo, porque cada instituição que continua italiana não pode acolher os filhos dos imigrantes e se se torna brasileira não pode garantir a italianidade". ${ }^{69}$

$\mathrm{Na}$ verdade, as autoridades italianas insistiam para que a coletividade evitasse qualquer tipo de atrito na expectativa de que tudo fosse resolvido, pois, em último caso, "era preferível que se procedesse ao fechamento das instituições do que aceitar a nacionalização de suas atividades”. ${ }^{70}$

Note-se, porém, que, segundo Trento,

muitas Associaçóes Dopolavoro, entre as quais a de São Paulo, optaram por se nacionalizar, mantendo as características, o tipo e o nível de atividade precedente, e até o acrônimo - $\mathrm{OND}^{71}-$ que, agora, passava a significar Organização Nacional Desportiva, com ênfase, até no nome, da cultura física. A partir de entấo, a ex-Opera Nazionale Dopolavoro foi dirigida por um conselho de vinte membros eleitos pela assembleia dos sócios, mas, como lamentavam os órgãos de segurança, "não há um único brasileiro da velha raça e os que continuam à frente dessa Organização vieram todos do Dopolavoro". ${ }^{2}$

É óbvio, como enfatiza Trento, "que a medida teve o efeito de obrigar algumas sociedades a se tornarem brasileiras, mas a opção que prevaleceu foi a da italianidade". ${ }^{73}$ Seja como for, o fato é que as cláusulas discriminatórias foram incluídas no Estatuto da SIU em assembleia extraordinária de setembro de 1939; o Artigo 45 ficou com a seguinte redação: "Fica expressamente proibida a admissão de brasileiros natos ou naturalizados, ainda que filhos de estrangeiros, em qualquer categoria do quadro social" ${ }^{74}$ Em realidade, de acordo com Perazzo, "as leis nacionalizadoras complementavam o projeto nacionalista de Getúlio Vargas na medida em que estavam incumbidas de restringir as atividades estrangeiras consideradas nocivas à constituiçấo da brasilidade". ${ }^{75}$ Assim, a SIU teve suas atividades encerradas.

\footnotetext{
${ }^{67}$ Ministro das Relaçóes Exteriores.

${ }^{68}$ ARCHIVIO STORICO DIPLOMATICO DEL MINISTERO DEGLI AFFARI ESTERI, Roma. Inventario della serie affari politici, 1931-1945, Busta 5.

69 ARCHIVIO STORICO DIPLOMATICO DEL MINISTERO DEGLI AFFARI ESTERI, Roma. Inventario della serie affari politici, 1931-1945, Busta 4.

${ }^{70}$ ARCHIVIO STORICO DIPLOMATICO DEL MINISTERO DEGLI AFFARI ESTERI, Roma. Correspondência de Galeazzo Ciano para Embaixada Italiana do Rio de Janeiro, 21/5/1938, Inventario della serie affari politici, 1931-1945, Busta 5.

${ }^{71}$ A OND - Opera Nazionale Dopolavoro (Organização Nacional dos Trabalhadores) - tinha como objetivo ocupar o tempo livre dos italianos e de seus descendentes por meio de diversas atividades culturais, com o intuito de difundir a propaganda fascista, conservar a italianidade, entre outros, sob a direção fascista e o permanente alerta do consulado.

72 TRENTO, Angelo. Organização operária e organização do tempo livre entre os imigrantes italianos em São Paulo (1889-1945). In: CARNEIRO, Maria L. Tucci; CROCI, Federico; FRANZINA, Emilio (Org.). História do trabalho e histórias da imigração: trabalhadores italianos e sindicato no Brasil (séculos XIX e XX). Sáo Paulo: Editora Universidade de São Paulo; Fapesp, 2010. p. 265.

73 TRENTO, Angelo. Do outro lado do Atlântico, op. cit. p. 292.

${ }^{74}$ SIU, Livro de Atas, 1 set. 1939, p. 260.

${ }^{75}$ PERAZZO, Priscila Ferreira. O perigo alemão e a repressão policial no Estado Novo. São Paulo: Arquivo do Estado, 1999. p. 42 .
} 
Sua última ata de convocação foi realizada, legalmente de acordo com os Estatutos, no dia 8 de novembro de $1941 .{ }^{76}$ Ela só foi assinada pelo secretário Augusto Zenerin. ${ }^{77}$

De modo geral, é claro que com o fechamento das instituiçóes italianas, como escolas e associaçóes, e a proibição do uso público da língua, os representantes das colônias não poderiam mais contar com as funçóes essenciais de construir, defender e fortalecer "a italianidade no seio da colônia italiana". Como se não bastasse, logo depois que o Brasil rompeu relaçóes diplomáticas com os países do Eixo - Itália, Alemanha e Japão - , em 1942, diversos navios mercantes brasileiros foram bombardeados pela marinha alemá. Declarava-se, então, a guerra contra os países do Eixo. Portanto, qualquer tentativa de conferir profundidade histórica à nacionalidade, por meio da italianidade, enfrentava obstáculos inultrapassáveis.

Além disso, estabelecido o estado de guerra contra os países do Eixo, Vargas determinou, por meio de decretos, o confisco dos bens pertencentes aos seus inimigos em potencial - italianos, alemães e japoneses - , para servir como indenização aos atos de agressão praticados pelos países em guerra contra o Brasil. ${ }^{78}$ Como consequência, a SIU teve seus bens bloqueados e sequestrados. Seu patrimônio social, um prédio no centro da cidade, como já comentado, estimado em 300 mil cruzeiros, foi doado à "Santa Casa de Misericórdia de Araraquara", no dia 26 de julho de 1946, depois de reiteradas tentativas judiciais impetradas pelos seus dirigentes na esperança de não o perder.

Aos vinte e seis de julho de mil novecentos e quarenta e seis (...) por Decisão de 19 de novembro de 1943,

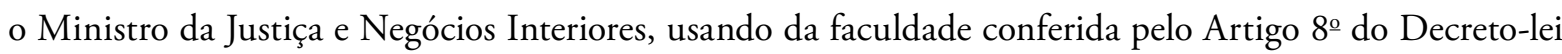
no 383 de 18 de abril de 1938, declarou dissolvida e extinta, para todos os efeitos, a Società Italiani Uniti (...) Confere ao Dr. Syrtes de Lorenzo (...) poderes para promover no Registro Civil de Pessoas Jurídicas do Cartório da Comarca de Araraquara o cancelamento da inscrição referente a Società Italiani Uniti, da mesma cidade, podendo ainda promover a lavratura da escritura de transferência do patrimônio social em favor da Santa Casa de Misericórdia de Araraquara. ${ }^{79}$

Já de posse da Santa Casa de Misericórdia de Araraquara, seu prédio foi vendido para o "Clube 22 de Agosto". De acordo com as anotaçôes de José Ferrari Secondo, ${ }^{80}$ "os maiores representantes da SIU foram ludibriados pelas autoridades brasileiras e italianas, além de colocar a colônia em situação de desprestígio". ${ }^{11}$ Náo sei, ao certo, o que Secondo quis dizer com essa frase, mas tudo indica que eles foram mal orientados pelos advogados brasileiros e abandonados pelas autoridades italianas. Também corre um boato na cidade de que o prédio social foi perdido por força dos interesses políticos locais.

\footnotetext{
${ }^{76}$ SIU, Livro de Atas, 8 nov. 1941, p. 275.

${ }_{77}$ Segundo Trento, em consequência das leis promulgadas pelo governo brasileiro, todas as organizaçóes do PNF no Brasil cessaram suas atividades (TRENTO, Angelo. Do outro lado do Atlântico, op. cit.).

${ }^{78}$ Decreto-Lei n. 4.166, de 11 de março de 1942: "Art. 1ํ - Os bens e direitos dos súditos alemães, japoneses e italianos, pessoas físicas ou jurídicas, respondem pelo prejuízo que, para os bens e direitos do Estado Brasileiro, e para a vida, os bens e os direitos das pessoas físicas ou jurídicas brasileiras, domiciliadas ou residentes no Brasil, resultaram, ou resultarem, de atos de agressão praticados pela Alemanha, pelo Japão ou pela Itália”. ARQUIVO DO ESTADO DE SÃO PAULO. Coleção das Leis de 1942. Imprensa Nacional: Rio de Janeiro, 1942. v. II, p. 323.

${ }^{79}$ SIU, Livro de Atas, 26 jul. 1946, p. 270 e 274.

${ }^{80}$ Ele era membro da SIU e, na época estudada, era considerado historiador local, pois tinha o hábito de anotar em livros todos os fatos pertinentes ao cotidiano da Araraquara e fazer colagem de recortes de jornais nesses livros. Tudo era escrito em língua italiana. Seu acervo encontra-se depositado no Arquivo Público Histórico Rodolpho Telarolli, Araraquara.

${ }^{81}$ SIU, Livro de Atas, s.d., p. 9.
} 


\section{Consideraçóes finais}

Os dados sugerem que a SIU manteve a colônia coesa durante os anos 1920 e talvez tenha alcançado o consenso da maioria nesse mesmo período. Todavia, a partir dos anos 1930 até o seu fechamento ficou evidente que ela foi decaindo; parece que a SIU foi abatida por um "recuo apático" ${ }^{22}$ por parte da colônia residente. Tudo leva a crer que, por motivo do seu espaço ter sido partilhado já pouco tempo depois de sua criação, a funcionalidade da SIU estava muito mais ancorada em conduzir os italianos a uma mesma identidade nacional do que, por exemplo, auxiliá-los em vista de suas necessidades materiais.

Certamente não se pode negar que, para a SIU promover a italianidade, ela deveria dedicar-se à tarefa da lenta edificação da identidade nacional. Para isso, as funçóes de construir, defender e fortalecer a italianidade no seio da colônia italiana exerceram um papel fundamental. Assim, uma longa série de iniciativas foi desempenhada por seus dirigentes na busca constante do processo de reconstrução da pátria no novo local de residência. As mais difusas dessas iniciativas se concentravam nas celebraçóes das festas nacionais italianas, nas quais tanto os afiliados quanto a colônia residente evocavam a "comunidade imaginada". Na verdade, as celebrações criavam oportunidades de estender e reforçar a construção da italianidade também fora do âmbito da própria associação. Do mesmo modo, a construção e a edificação da sede social tinham como objetivo, entre outros, a identificação dos italianos com o espaço nacional. Além do papel aglutinador, a SIU funcionava como elo permanente dos afiliados com a pátria, preparando-os constantemente para a (re)valorização da nacionalidade e para a construção, defesa e fortalecimento da italianidade. Concluindo, a SIU deu uma importante contribuição para a consolidação da italianidade na colônia italiana.

\footnotetext{
${ }^{82}$ COSER, Lewis A. Consenso. In: OUTHWAITE, William; BOTTOMORE, Tom. Dicionário do pensamento social do século XX. Rio de Janeiro: Jorge Zahar, 1996. p. 132.
} 